\title{
Linguistic Features of Internally-Focalised Discourse in Ngũgĩ wa Thiong'o's Matigari
}

\author{
Yémalo C. Amoussou \\ FLASH/UAC-Bénin Republic, West Africa \\ Email: Cayemal@yahoo.fr
}

\section{Doi:10.5901/mjss.2017.v8n1p377}

\begin{abstract}
This paper applies the systemic functional linguistic theories of mood and transitivity to about 40 strings of internally-focalized discourse from Ngũgĩ's Matigari (1987) to uncover the major characteristics of this form of discourse in this particular work and to see, when applied to others, how consistent they might be. Not only do the findings confirm the indicators of this form of discourse as expounded by narrative theorists such as Uspensky (1973), Barthes (1974), Genette (1980), Rimmon-Kenan (1983) and Fowler (1986), but they also add that the choice of character can greatly influence these features.
\end{abstract}

Keywords: focalisation, process, mood, modaliser, modulator, rewriteable discourse, generic sentence

\section{Introduction}

Linguistics-oriented analysis of literary works like novels always poses two major procedural problems. One practice consists in taking a few extracts, accounting for $5 \%$ maximum of the novel, describing them and projecting the findings to the whole (Halliday, 1967; 1970; 1971; Hasan, 1985/89; Chabi, 2004; Yokossi, 2005; Agbachi \& Egouleti, 2007; Ahouanvoedo \& Gbékpodé, 2009, etc). The other is to apply linguistic theories to these extracts as if they were from ordinary informational discourse. These practices certainly trace back to the influence of Halliday's early position on the literature-linguistics relationship, as he (1970) states:

The linguistic study of literature is textual description, and it is no different from any other textual description; it is not a new branch or a new level or a new kind of linguistics but the application of existing theories and methods. What a linguist does when faced with a literary text is the same as he does when faced with any text that he is going to describe (p.67, my emphasis).

Both approaches can lead to inaccurate pronouncements on fictional works: analysis of two/four extracts cannot stand for that of a whole novel just as that of literature without regard to its peculiarities would be meaningless (Jakobson, 1960: 377; Culler, 1975:114; Widdowson, 1975:3; 14; Littlewood, 1976: 22; Brumfit \& Carter, 1991: 8; etc). Narrative fiction gives room for the inclusion of such modes as dreams, reveries, interior monologue and visual/aural vistas, which are not that common in ordinary discourse (Littlewood, 1976, Ngũgĩ, 1981). It thus stands to reason that a lexicogrammatical analysis, i.e., Transitivity, Mood and Theme analyses (Eggins, 2004; Halliday \& Matthiessen, 2004) of a literary text needs taking into account specifics of its mode.

This paper thus aims to emphasise the necessity to take into account such aspects as modes of focalisation in carrying out a transitivity analysis of narrative fiction in general, and of internally-focalised discourse mode in particular, as this will influence considerations for mood analysis (Fowler, 1986; Amoussou, 2014). In addition, as linguistics is objective and systematic by definition (Crystal, 1968: 28), this requires a more comprehensive selection of extracts for analysis. The next section defines the key concepts underpinning the paper.

\section{Conceptual Definitions: Internally-Focalized Discourse, Mood and Transitivity}

The concept of "focalisation" basically "concerns the question of who is presented as the observer of the events of a narrative, whether the author or a participating character; and the various kinds of discourse associated with different relationships between author and character" (Fowler, 1986: 134). Drawing on the narrator-character relationship and the associated kind of discourse, Genette (1980) distinguishes between 'internal focalisation,' 'external focalisation,' and 'zero focalisation,' only the first of which is being focused on in this paper.

The narrative mode in which the internal focalisation is more fully realised is the internal monologue. This is what 


\section{Dujardin (1931) refers to in defining interior monologue as:}

a discourse without an auditor and unspoken, by which a character expresses his most intimate thoughts, those closest to the unconscious, prior to all logical organization, or, simply, thought in its dawning state -expresses it by means of direct phrases reduced to their syntactical minimum, in such a way as to give the impression a hodgepodge (p.59).

This definition applies more strictly to the 'direct monologue', in which the character thinks or talks to himself/herself, as opposed to what Cohn (1966) calls 'narrated monologue', i.e., the technique of internal depiction of a character's thoughts by the use of the third-person narrator and the tense of narration. In the former, at both the surface and deep structure levels, the thinking character is the author of the thoughts but in the latter, the external narrator's intrusion is felt on the surface structure through the use of free indirect discourse devices and modality, even though on the deep structure level, the thinker, not the reflector, is the direct author. In this case, careful reading is needed to tell the narrator's participation from the characters'. In this regard, Barthes (1974) suggests a test to see whether a narrated discourse string is internally focalised or not: when a discourse sequence that is not initially in the first person can be rewritten into that person without the need for "any alteration of the discourse other than the change in grammatical pronouns (and tenses)" (p.262), then it is internally focalised. When it cannot, then it is externally focalised. This test is applied to sequences in the extracts under study.

Drawing on the definition of 'mood' as the "name given to the different forms of the verb (indicative, interrogative, imperative, subjunctive, exclamative, etc) that are used to affirm more or less the thing in question, and to express... the different points of view from which the thing is looked at' ( p.161), Genette (1980) contends that this capacity to tell a story from one point of view or another and its modalities of use constitute narrative mood (pp.161-2). He further argues that this transposition of grammatical mood to the 'representation' and 'regulation' of narrative information relies purely on pictorial analogy as one's view of a picture depends on one's position to it (p.162). It must be pointed out that the 'representation' of experience is achieved through the 'transitivity grammar' while its 'regulation' is so through 'modality', an important component of the mood grammar (Halliday, 1971; Fowler, 1986; Eggins 1994/2004).

Though the term 'transitivity' is variously defined (Halliday, 1971:354; 1973: 39; 1985a:101; Lyons, 1977), Eggins' (1994) definition as "the description of the clause as a representation of experience" (p.99) is more relevant here to restress the transitivity-mood link made earlier. Indeed, Fowler (1986) hints to the mood contribution to 'transitivity', as he sees it as 'the point of view' from which the 'reality/experience' is represented or grammaticalised". For him, transitivity patterns/choices can indicate a certain mind-set a world view framed by authorial ideology: "linguistic codes do not reflect reality neutrally; they interpret, organise, and classify the subject of discourse. They embody theories of how the world is arranged: world-views or ideologies" (p.58). Though, transitivity analysis involves taking into account "processes, participants and circumstances" (Lyons, 1977; Halliday, 1985a; Eggins, 1994), this paper keeps to the first aspect for space and relevance reasons. The various processes a character can perform in fall into 6 broad categories: (1) transitive material processes (=TMPs), that is, non-verbal physical actions, (2) middle material processes (=MMPs), that is, verbs denoting physical movements, (3) mental processes (=MePs) -verbs of perception, affection and cognition, (4) behavioural processes (=BePs), i.e., verbs denoting physiological and psychological actions or reactions), (5) verbal processes (=VPs), (and (6) existential(EPS) and relational processes (RPs) (Chatman, 1978; Eggins, 1994). In addition, the label 'RR' stands for 'rewritable'

Rimmon-Kenan (1983: 81), drawing on Uspensky (1973), lists some transitivity and mood features of internal focalisation:

When the focalized is seen from within, especially by an external focaliser, indicators such as 'he thought', 'he felt', 'it seemed to him', 'he knew', 'he recognized' often appear in the text. On the other hand, when the inner states of the focalized are left to be implied by external behaviour, modal expressions - suggesting the speculative status of such implication -often occur: 'apparently', evidently, 'as if', 'it seemed', etc. Uspensky calls these 'words of estrangement' (1973:p.75) (my italics).

While the five verbs listed in the quote belong to the group known as 'mental processes,' the modal locutions cited similarly belong to the super-ordinate known as 'modalisers' or 'weakeners." Fowler (1986) claims that the intense use of these modalisers, to which he adds items like 'can, may, might, perhaps, maybe, as though, looked, appeared, etc', marks subjectivity or caution or partiality. The same also argues that the profuse use of modulators like 'must, need, should, ought to, had better, can't, etc' and of generic or proverbial sentences emphasise the confidence, power, obligation, necessity, and truth-hood, of the utterances made. As such, it can strongly be argued that internally-focalized discourse offers some good ground for the joint exploration of mood and transitivity grammars. Like the transitivity 
analysis, the mood one basically keeps to mood and modality types.

\section{Methodological Considerations}

For the purpose of this analysis, almost all the internally focalised passages in the novel have been systematically identified. After justifying, through transitivity features why each extract is taken as such, it is subjected to mood analysis through breaking down into mood types and identifying modality elements. The mood label ' $D M$ ' stands for 'declarative mood', 'IM' for 'interrogative mood', 'EM' for 'exclamative mood' and 'IMP' for 'imperative mood'; ' $M+$ ' for 'modulator', ' $M^{-}$' for 'modaliser', PS/GS' for 'proverbial/generic sentence.' The findings from the analysis are summed up and discussed on the basis of contextual factors.

It can be noticed that some combinations of "be/feel+ feeling/attitude denoting adjectives" are taken as either mental or behavioural processes due to their semantic import. Out of context, such combinations would be taken as 'intensive relational processes', a phrase which does not fully reflect their experiential meaning in context. So "be + hungry" is taken as a BeP due to its semantic closeness with "to hunger for, to eat" and "be + angry" as an MeP as a result of its semantic proximity with "to anger, to like, to hate, to please, to disgust", etc (Amoussou, 2011; 2014). In addition, phrases like 'said to himself', 'told himself', ' asked himself', 'murmured to himself, etc., are taken 'MePs' as they are near synonyms with mental processes like 'to wonder, to mutter, etc.'. What is more, such expressions signal interior monologue/stream of consciousness, which Fowler (1986) sees as a "directly experienced mental process" (p. 137). As the characters' words are included in/governed by the narrator-worded mental processes, they are considered just for the mood analysis in each extract while the narrator's ones are so for both the transitivity and mood analysis. Finally, all the extracts that are the longer than six lines $\left(n^{\circ} \mathrm{1}, 2,4,6,8-10,12,15,16,25,30-33,36, \& 37\right)$ are referred to with their boundaries, with only $n^{\circ} 1$ fully cited in the analysis as an example: (1) [(p.3) "It reminded him of.....into Hell" (p.3)]; (2) [(p.4) "He went down to...... rebuild my home" (p.5)]; (4) [(p.5) "He yawned drowsily...... and woke up" (p.6)]; (6) [(p.7) "He walked along...... all the searching myself' p.8) ]; (7) [(p.8) "His thoughts now turned to......... had stolen from the people" (p.8.)]; (8) [(p.9) "He watched them..... where the people worked(p.9.)]; (9) [(p.10.) "Why on earth has he.....? ...in broad daylight?" (p.11)]; (10) [(p.12) "He found (\#) [[the two policemen.... not go home alone]" (p.12)]; (12) ["Then and now.......... a people united cannot do" (p.16)]; (15) [(p.26) "He just looked at... and join others" (p. 27)]; (16) [(p. 27) "What a beautiful woman........ in a dingy bar?" (p. 28)]; (25) [(p.88) "Matigari set off....... rather than lukewarm like this" (p.89)]; (30) ["He made the decision........ comes from a sharpened spear" (p.131, writer's italics)]; (31) [(p.150) "Each was preoccupied....... in the wilderness with a woman" (p.151)]; (32) [(p.160) "Matigari wondered.......... the armed might of the united dispossessed" (p.161) ]; (33) [(p.162) "How did they know........... the way of Irigi revolutionaries" (p.163)]; (36) [(p.166) "Boy's house is burning! .........Burn Parrotology -burn! (p.169)"]; (37) ["When John Boy Junior heard... some of them concluded" (p.169)]. The shorter sequences $\left(n^{\circ s} 3,5,7,13,14,17-24,26-29,34,35\right.$, \& 38-41) fully appear in the analysis. The next section applies the theoretical concepts discussed above (transitivity, mood, and modality) to determine the features of internal focalisation in the novel.

\section{Mood and Transitivity Features of Internally-Focalised Discourse in Matigari}

It can be stated from the start that the instances of internally-focalised discourse in this novel are characterised by the inclusion of strong mood-types (interrogative, exclamative, imperative, generic sentences) and rewriteable microdiscourse strings within macro-mental processes like 'reminded,' 'remembered,' 'thought, 'and 'recalled,' For instance in extract 1, the occurrence of $04 \mathrm{MePs}$ for which Matigari is the sole senser attests to the fact that the discourse string is internally focalised (Rimmon-Kenan, 1983).

(1) ["It reminded (MeP) him of the horses] (DM) [that Settler Williams and his friends had often ridden (MMP) ](DM) as [they went (MMP)to hunt foxes accompanied by packs of well-fed dogs.](DM)] [lt felt like ${ }^{(M e P)}$ so long ago] (DM); [and yet....... $]^{D M}$ [How the settlers had loved (MeP) shedding blood!] EM ... (\#) [[They would dress (BeP) in red] ${ }^{D M}$, and [the rider [who got $\underline{\text { to }}^{(M M P)}$ the fox first] (DM) would cut off (TMP) its tail in triumph] (DM); then [he would smear (TMP) the blood of the fox on a woman.. $]^{(D M)}\left[\right.$ Yes, it felt like ${ }^{(M e P)}$ a long time back. ${ }^{(D M)}$... [Well, there was no night so long that it did not end with dawn]

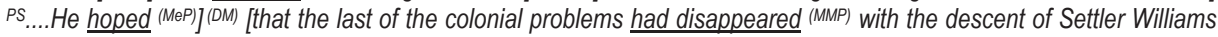
into hell] (DM) (p.3.)

It must also be noted that the first 02 MMPs are included within the direct object of the MeP 'reminded' just as the last one is within that of the MeP 'hoped'. Likewise, the other MPs are included in the clause containing the MeP 'had loved.' Though there occur as many as 11DMs, there is 01EM to introduce the section marked by (\#\#) [...]) and 03 
modalisers -'would, would, would' - expressing, in this context, past habitual. In addition, there is 01 PS -"there was no night so long that it did not end with dawn" (p.3) - to illustrate the last MeP 'hoped'. This is the narrated version of the Gikuyu proverb "gũtirĩ ũtukũ̃ ữtakỉa" used to keep faith in hope (Ngũgĩ, 1981:172).

Despite the presence of 04 MMPs, 03RPs and 01 TMP in the first paragraph of extract 2, the use of 02 macroMePs, 'reminded' or 'remembered' and 'murmuring to himself', to introduce the 02 memory sections - "(\#) [['how, then, they had sung......struggle to come" (p.4)]] and "\#[['it's good that .... rebuild my home"' (p.5)]] - shows that the character is seen from within (Uspensky, 1973; Rimmon-Kenan, 1983, Amoussou, 2014). Indeed, these MePs include/cover the marked sections after them which serve as their direct objects. The first marked section, which can be rewritten (Barthes, 1974; Genette, 1980), contains 02 other MePs and 03 BePs, which confirms the interiority of the focalisation. The dominant mood is DM, 12 in number, but there are 05EMs. In its paragraph 2, the $01 \mathrm{BeP}$ and the $02 \mathrm{MePs}$ show that the character is shown from within. This is re-enforced by the presence of 02 strings of monologue. It must be noted that the first 02 MMPs help to introduce the main-clause $B e P$ 'looked at', which in turn introduces the MeP that includes the first monologue section. The last 02 TMPs play the same function for the MeP that includes the second monologue section. All the 12 clauses are in DM, there are 04 modal locutions in the monologues: 02 evaluative locutions 'It's good that, instead' and 02 modulators 'shall, shall'. The $03 \mathrm{MePs}$ and $02 \mathrm{BePs}$ in (3) are indicators of an internally-focalised character (Uspensky, 1973; Rimmon-Kenan, 1983; Amoussou, 2014). Moreover, there is a narrator-rendered but character-thought PS: "But there was no arrival without the effort of moving feef". In addition, there are 04 EMs; the first 03 of which express the character's indignation at the hot weather, and the last one, which expresses his hope, is rewritable into the first person (Barthes, 1974). In this string the modulator 'would' shows the focaliser's determination to find and rebuild his long-deserted home.

\begin{abstract}
(3)[He was sweating (BeP).] (DM) [So much heat!] (EM) [So much dust!] (EM) [What trials one had to endure on this earthly journey!] (EM) [But there was no arrival without the effort of moving feet.] (DMPS) [He tried to visualise(MeP) his home.] (DM) [In his mind's eye he could see (MeP) the hedges and the rich fields so clearly] (EM). (RR)[[Just another climb, the final climb]] ${ }^{(E M)}$ and [then he would be home - his home on top of the hill!] (EM)] His feet felt heavy (BBP). He decided (MeP) to rest for a while (p.5) (my emphasis).
\end{abstract}

The fourth extract contains $04 \mathrm{BePs}$ and $01 \mathrm{MeP}$, which indicates a psychologically-probed into character (Uspensky, 1973; Rimmon-Kenan, 1983). It must also be pointed out that the character's monologue is included between the $\mathrm{MeP}$ 'took flight' and the BeP 'startled up'. Moreover, his mental questions result in a good number of IMs, 06 in all, 04 of which are strongly modulated with locutions like 'how could I?, how can I?; how can I? Could I?' This strong tenor shows the character's indignation not only at wanting to go home alone but also at forgetting the aim of the solidaritybuilding song sung during the independence struggle. His own answers to the questions are expressed in 18 DMclauses, 07 of which are strongly modulated with 'must, must; must, shall, shall, shall; shall'. There also is 01GS/PS and 01 modaliser 'used to' in this quote.

In (5), a macro-MeP is used to introduce an RR-string (Barthes, 1974; Genette; 1980):

(5) ["He had made up (MQP) his mind.] (DM) (HRR) [[He would first go (MMP) in search of his people] (DM); [at least first (he

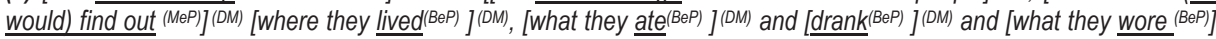
(DM)]. [So many traps] ${ }^{(E M)}$, [oh so many temptations, in the way of the traveller on this earth!] ${ }^{(E M) " ~(p .6 .) ~}$

In addition to $01 \mathrm{MMP}$, this RR-string contains $01 \mathrm{MeP}$ and $04 \mathrm{BePs}$ which emphasize the character's psychophysiological concern. Apart from the 02 elliptical EMs, there are 06 DM-clauses, in which all the processes are included. As for extract $n^{\circ} 6$, despite the occurrence of 02MMPs and $01 \mathrm{RP}$ in its narratorial section, it is mainly characterised by 03 contextual macro-MePs 'floated after, drifted from, strayed back to': the first one covers the first memory section "(\#) [[United States ... water racing" ]]", which contains 05 elliptical DMS, the second one governs the second section "(\#) [[Some had....Africans"]]". with 03 DMs with 03 RPs, and the last one hinges between the 02 marked monologue sections: "\#) [[Long, long before.... and ships"]] and "\#) [[How many lives..... had stolen from the people"]]". It must be noted that the occurrence of these MePs and the rewritability of the first interrogative in the last marked section into the first person are good indications of internally focalised discourse (Barthes, 1974; Genette, 1980). There are 10 other DMs, 01 of which is elliptical and negatively polarized, $07 \mathrm{IMs}, 01 \mathrm{EM}$ and 05 strong modulators 'could...not, could ever, would, should, shall' in this extract.

In extract 7, there are 06MePs, all of which have Matigari for senser, 03 TMPs, all of which are passivised, and $02 \mathrm{BePs}$, the last of which is figuratively used as it has 'it/the railway,' an unconscious being, for behaver. Though the dominant mood-type is DM (06), there are 02 IMs, which express the thinker's indignation at the casualties of the railway. 
It must also be noted that the BeP 'shivered' is used here as a macro one as all the clauses coming after it serve as 'complement' to it. As for $n^{\circ} 8$, it contains, apart from $01 \mathrm{TMP}$, as many as $12 \mathrm{MePs}$ and $01 \mathrm{BeP}$-for which Matigari is the dominant senser and behaver. The apparent MPs 'had been battered' and '(had been) broken' are taken as MePs because their subject includes the item 'minds'. Though the dominant mood is DM (19), there is a good proportion of IM (08), 02 of which are elliptical, 02 rewritable GSs, the last two sentences. In addition, there occur 06 strengtheners 'really, cannot, will not, shall, really, ought to' which all appear in Matigari's mental discourse. However, there is 01 estranger 'as if' signalling the external interpretation of the narrator.

Similarly, extract $n^{\circ} 09$ contains just 01MMP and 01 TMP but as many as $07 \mathrm{MePs}$ and $01 \mathrm{BeP}$ for which Matigari is the senser/behaver. The occurrence of these MePs and of 03 RR-clauses shows that the discourse is internallyfocalised (Barthes, 1974; Rimmon-Kenan, 1983). This is reinforced by significant number of self-interrogations (10) which are in turn strengthened by 03 IPMs and 07 modulators 'would, was bound to, could not, shall, shall, shall, could...be possible'. The strong tenor set by these moods and strengtheners is epitomised by 02 PSs: "Victory is born of struggle. There is no night so long that it does not end with dawn" (p.11), even though there are 02 modalisers 'perhaps, might' that have some softening effect on discourse tenor.

Though there are 04 MPs, 01 TMP and 03 MMPs, in extract 10, these are either negated or located in rankshifted clauses. The $04 \mathrm{MePs}$, all of which have Matigari as senser, are narrator-rendered perceptions of the character. The MeP 'found' has for direct object the whole visual-mental section "(\#) [[the two policemen with ........ go home alone"]]" while the last $\mathrm{MeP}$ introduces the last 02 rewritable clauses. The portion 'it was questions.......mountains' can also be rewritten. There are $13 \mathrm{DMs}$ and $04 \mathrm{IMs}$ in this quote. As for extract 11, it contains 02 unspoken and rewritable IMs included between a BeP-clause and an MeP-one, both in DM:

(11) ["His heart skipped a beat (BeP).] (OM)) (\#RR)][How was he going to tell this boy] [that he had spent all his life struggling for a shelter?] [(M) [That he had spent many years fighting Settler Williams for the sake of his children?]] ${ }^{(M)}$ [He thought of (MeP) telling the boy the story of his life's struggle with Settler Williams, in the forests... all over the country" ] (DM) (p.15.)

There are only $03 \mathrm{MePs}$ and $01 \mathrm{BeP}$ in extract 12, presumably because it contains a remembered song section and the last $\mathrm{MeP}$ 'saw' has for direct object the whole section "(\#)[[a vision of himself........ a people united cannot do.]]" As it appears, the discourse is broken, with as many as 07 suspension dots, just like $n^{\circ} \mathrm{s} 1,6,8,15 ; 18,26$, and 33 . There occur about 13 DMs, 03 of which are elliptical, 04 IMs, 01 elliptical EM and 01 GS modulated with 'cannot'. There also are 03 modulators 'would, would, would' to express the character's determination to, or strong belief in, the accomplishment of his vision. Extracts (13) and (14) contain $06 \mathrm{MePs}$, the first 04 of which are figuratively used, and 01MMP. While these processes occur in $06 \mathrm{DMs}$, they help to introduce and end $06 \mathrm{IMs}, 03$ of which are strongly modulated with 'should, should, will,' even though the modaliser 'seemed' marks both narratorial externality and subjectivity (Rimmon-Kenan, 1983; Fowler, 1986; Amoussou, 2014; 2015):

(13) [Many questions flashed through(MeP) his mind, ] (DM) but no answer seemed to offer(MeP) itself. ] (DM)They all culminated(MeP) into one big question](DM): [what curse has befallen us] (MM) [that we should now be fighting one another?] $]^{(M)}\left[\right.$ That children and their parents should be fighting] ${ }^{(M)}\left[\right.$ while our enemies watch with glee?"] ${ }^{(M)}(p .18)$.

(14) "[He turned(MMP)](OM) and looked at (MeP) Muriuki.] (OM) [Will the day come] ${ }^{(M)}$ [ when our orphans can wipe away their tears?] ${ }^{(M)}\left[\right.$ He thought ${ }^{(M e P)}$.] ${ }^{(D M)}$ (p.26)

In $n^{\circ} 15$, an 8-clause rewritable monologue - (\#) [[When he had come .... begin the search" ]]" - appears between the MePs 'thought about' and 'came on' while a 5-clause soliloquy - "(\#) [[Indeed, women were...... in the homestead"]]"does between the BeP 'started' and the MeP 'wondered'. These monologues and the $05 \mathrm{MePs}$ and $02 \mathrm{BePs}$ that introduce them show Matigari as the character focalised from within. It must be pointed out that it is Matigari who 'hears' and reacts to the radio news in the stream-of-thought string "Indeed, women...homestead" (p.27). That is why the process 'came on', which is verbal when 'the radio' is 'subject', is taken as 'mental', synonymous with 'heard'. The dominant mood is DM,17 in all, 02 of which are modulated with 'should, would' but there is 01 elliptical IM, 1 EM and 02 GSs, introduced by 'indeed' to stress their veracity. Likewise, the physical description of Gũthera in (16) is a Matigariborne stream of consciousness as announced by the MeP "thought". This extract contains a series of 10 elliptical EMs introduced or factorized with 'what', and 'see' and emphasized with 'so, so...that, so...that, too, too, too, too, yes, such', 09 in all, which, in this case, act as strengtheners/modulators (McCornell-Ginet et al, 1980; Fowler, 1986). There also is 01 strong metaphor of modality "it was difficult not...", $01 \mathrm{IM}$ and 03 estrangers "as if, as though, like". While the EMs and intensifiers express the thinking character's admiration and celebration of the "rare beauty", the estrangers simply show 
that those are impressions of a character watching and interpreting subjectively another's states/actions (Uspensky, 1973; Rimmon-Kenan, 1983). As for the metaphor of modality, which can be rephrased as 'one could not help+ gerund', it somewhat rejects the subjectivity implied in the estrangers to give way to some absoluteness/certainty about the woman's beauty (Halliday \& Matthiessen, 2004). This strong tenor is confirmed by Matigari's mental $E M$ and IM at the end of (17):

(17) ["Matigari held (BeP) his chin, sadly contemplating (MeP)] (DM) [what had taken (MMP) place] (DM). [Age crept back (BeP) on his face](DM); [the wrinkles seemed to have increased (BeP) ](DM) and [deepened (BeP)] (DM). [How everything had changed!] (EM) [What was this world coming to?"] ${ }^{(M)}(p .29)$

In addition, the evaluative adverb 'sadly' is enough to point to the focaliser's psychological outlook, which is reinforced by the increase of wrinkles on his face. All this indicates that that Matigari is the first-and-second-level focaliser of the events in the bar and that the narrator is on the third level, as the estranger 'seemed' shows (Rimmon-Kenan, 1983).

In this description of Matigari's reaction while Gũthera is harassed by the police, one sees a transition from indirect to direct interior monologue:

(18) [A feeling of sharp pain and anger flashed through (MeP) Matigari] (DM). [His hand moved to (MMP) his waist.....](DM) [He

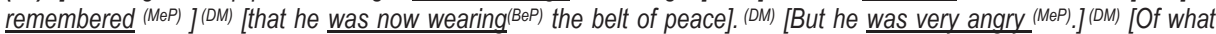
use is a man] ${ }^{(I M)}$ [if he cannot protect his children?] ${ }^{(M)}$ [However, he did not wrap up (MeP) his anger in silence] [(DM). [It is no use getting angry about things, ](DM) [he had always told himself (MeP), ](DM) [if you have no intention of doing something to change them] (DM-GS) (p.30)

Though there is $01 \mathrm{MMP}$, the $05 \mathrm{MePs}$ and $01 \mathrm{BeP}$ testify to the interiority of the focalisation. In addition, there are 02 strings of unspoken monologue, as can be seen in the italicised sections. The first is both interrogative and modulated with 'cannot' while the second one is generic and modulated with the phrase 'it is no use," a substitute of 'needn't.' The (19-21) below stand for 03 strings of unspoken discourse, 02 of which are borne by Gũthera $(19,20)$ and $01(21)$ by Mũriũki:

(19) [Gũthera contemplated(MeP) the question for a while] (DM). [Throughout their conversation she had been

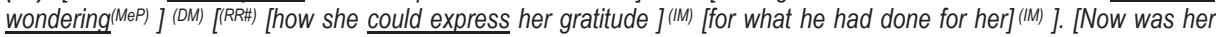
chance] ${ }^{(D M)}$, and [she seized (MeP) it] ${ }^{(D M)}$. [Whether he was crazy or not was beside the point. (DM) [She thought $\left.{ }^{(M e P)}\right]^{(D M)}$ : [I will go with him $]^{(D M)}$, [ (will) support him] ${ }^{(D M)}$, [until he finally finds his people" $]^{(D M)}($ p.39).

(20) ["This man has indeed spent a long time in the forest(DM)], [she thought to herself(MeP) (DM). [He should first go home] and [sleep of the fatigue of many years] (DM). [Who but a stranger would not know that] [ the police in this country were always fighting against students and workers?] (IM)" (p.40).

(21) [Mũriũki felt tired (BeP)] ${ }^{(D M)}$ and [ached (BeP) all over] (DM). [When he looked at (MeP) Matigari](DM), [he could not help wondering $\left.{ }^{(M e P)}\right]^{(D M)}$ : [what sort of man is this?] ${ }^{(M)}$ [I haven't seen him eat or drink anything] ${ }^{(E M)}$, and [he does not look in the least tired!] (EM)" (p.41).

While $n^{\circ} 19$ contains $04 \mathrm{MePs}$, which marks internal focalisation, it ends with Gũthera's decision to grant Matigari full support come what may, as signalled by the modulators 'will, will'. As for $n^{\circ} 20$, it airs the woman's surprise at Matigari's ignorance of the recurrent police brutality against workers and students, as signalled by the modality metaphor 'Who but a stranger would not know that...' (Halliday \& Matthiessen, 2004). In (21), the 02 BePs signal the young character's physiological suffering while the unspoken section, with $01 \mathrm{IM}$ and 02 EMs, shows his surprise at Matigari's endurance on an empty belly. In $n^{\circ} 22$, the 02 MMPs help to transit to the perceptive MePs 'watched, see' which in turn, help to present Gũthera and Mũriũki as the focalisers of the scene:

(22) [Gũthera and Mũriüki had already stopped(MMP) behind a cluster of bushes] (DM), and [they watched (MeP) from a safe distance] (DM) [ (in order) to see ${ }^{(M e P)}\left[\right.$ what was going to happen ${ }^{(M M P)}$ ] (DM). [They were each asking themselves ${ }^{(M e P)}$ the same question] (DM): [Is this man sane? ] (IM) [Were these not the houses] (IM) [which had once belonged to the colonialist settlers] (IM) but [now belonged to the very rich, the foreign and local people of all colours -black, brown and white? ] ${ }^{(I M)}$ [Yet, Matigari seemed to have no(MeP) qualms or any inhibitions] (DM) (p. 43.)

Moreover, the cognitive $\mathrm{MeP}$ 'were each asking themselves' helps to introduce their 02 mutual self-interrogations and the modaliser 'seemed' confirms their position as second-level focalisers ( Amoussou, 2011; Rimmon-Kenan, 1983).

In $n^{\circ} 23$ and 24, the tenor similarity between the narrator and character-focaliser comes out as the latter's heart- 
song in (23) contains, in addition to Matigari's usual question, 04 of the 07 GSs uttered by the narrator in (24):

(23) "A farmer does not stop sowing because just one crop has failed. The seeker of justice does not stop searching until he finds it. Truth never dies. Justice is mightier than strength. Tell me: where on this earth can one find truth and justice?" (p.86).

(24) "The true seeker of truth never loses hope. The true seeker of real justice never tires. A farmer does not stop planting just because of the failure of one crop. Success is born of trying and trying again. Truth must seek justice. Justice must seek the truth. When justice triumphs, truth will reign on earth (p.84).

The modal activity here is signalled by 07 visible modulators 'never, never, never, must, must, must, will' which show both the character's and narrator's rejection of injustice and their belief in the certainty of the victory of truth/justice over falsehood/injustice. This certainty is stressed by the triple use of the polar negative 'does not, does not, does not'.

Apart from the MMP 'set off,' extract $n^{\circ} 25$ contains $11 \mathrm{MePs}$, which indicates a character focalised from within. It must be noted that the phrases 'became his agony' and 'became his suffering' are taken as MePs because they can simply be replaced by 'agonised with' and 'suffered with' (Amoussou, 2011; 2014). On the mood side, the extract contains 07 mental IMs and 01 IMP, which justifies the thinker's adamant need to find truth and justice, and 02 GSs. The IMs, the IMP and the DMs in this section are introduced by 02 macro-MePs 'didn't think' and 'asked himself' and are highly modulated or tonal: "Let me start ...", "how can I ...?"; "how can It...?"; "how can I ...?"; "...how long shall ...?"; "who shall ...?" His determination to continue his search come what may is articulated through the double modulator 'will never'. The remaining clauses are introduced by the stressed MeP 'felt strongly' and are all rewriteable into the first person (Barthes, 1974) and are strongly modulated 'had to, had to, it would have been better, (it would have been) better ..... yes, (it would have been) better.....rather than'; 05 modulators in all. These modulators help to reinforce the strong tenor set by the interrogatives and imperatives.

Extracts 26 and 27 below are Matigari-borne streams of thought, as is signalled by the $M e P$ in (27). The whole of 26, with 04IMs, is rewriteable (Barthes, 1974; Genette, 1980) while (27) is made up of 02 GSs introduced by 01 DM, and 02 IMs:

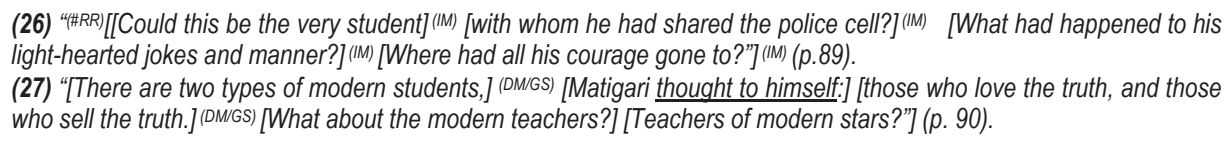

In 28-29, the narrator somehow enters people's mind to tell their reaction to Matigari's show of courage:

(28) "[Everyone turned (TMP) their eyes to the door]. (DM) (They saw) (\#) [[A tall, well-built, elderly man stood (MMP) in the doorway...... $\left.]^{(D M)}\right]\left[\right.$ His hands were ${ }^{(R P)}$ inside his coat pockets,] (DM) [as though he were holding (TMP) something....] (DM) [Everyone stood(MeP) in silent admiration] (DM). (\#RR)[[They could not believe(MeP) j(DM) $^{(\text {that anybody could be so brave }}{ }^{(M e P)}$ as to ask a question ](DM) [after what had happened(RP) to Ngagũro wa Kiririro....] (DM)"] (pp.111-12).

(29) "[Matigari stood (MMP) in the midst of the people] (DM). [And the people stood (MeP) silently in total admiration] (DM) (सRR)] [What a long time it had been ${ }^{(R P)}$ ] (EM) [since they had last seen (MeP) such courage! ] ${ }^{(E M)}$ [So it was true ${ }^{(R P)}$ ] ${ }^{(E M)}$ [that the patriots of long ago were still alive(BeP)! ] (EM) [So the patriots of the land had finally returned (MMP)to help them claim their own!"] $\left.{ }^{(\mathrm{EM})}\right]$ (pp. 114-15.)

While these quotes contain $03 \mathrm{MMs}, 02 \mathrm{TMPs}$ and $04 \mathrm{RPs}$, they also include $05 \mathrm{MePs}$ and $01 \mathrm{BeP}$ for which 'everyone/people' is senser/behaver. It must be noted that the first string marked (\#[...]) in (28) serves as direct object for the elliptical MeP 'saw' while the second marked section is rewritable into the first-person plural. In (29), 'stood' is first taken as an MMP (physical action) and then as an MeP (affective process). In addition, the marked section is rewriteable. Though the evaluative phrases 'in silent admiration,' and 'in total admiration' show the degree of people's feeling for Matigari, the modal locutions 'could not believe that', 'so it was true that' enhance that courage. This paramount admiration is epitomised by the 05 EMs that end (29), even though there are 10 DMs.

The $02 \mathrm{MePs}$ that introduce extract 30 indicate that it is internally focalised. It must be noted that the section "(\#)[[that one could not......... armed with armed words"]]" serves as a complementiser for the MeP 'it dawned on him'. While the 02 modulators 'could not, could not' express the impossibility for the word or action alone to beat the enemy, the other 03 - 'had to, had to, had to' - show the necessity to combine action/armed struggle with the word/political one. In particular, these 05 strengtheners appear in clauses that have the generic 'one' for subject and, thus, must be seen as GSs with a function similar to metaphors of modality (Fowler, 1986; Halliday \& Matthiessen, 2004). This combination of 
generics and modulation give these clauses the status of undeniable truths (Fowler, 1986; Halliday \& Matthiessen, 2004). Moreover, the double IMs 'did he..., did he not...' in the story about the blacksmith and the ogre stress the primacy of action before the word. Indeed, the other GS that ends $n^{\circ} 30$, which are italicised by the writer, not only sum up the focaliser's approach to political struggle, but also the scripter's sharing in that. This ideological complicity between the narrator/writer and the character-focaliser leads to a conflation of narrative functions (Amoussou, 2006; 2011.) This very complicity is further noticed in (31) where the GS used by the narrator (23) and Matigari (24) reappears. Though there are $01 \mathrm{TMP}$ and $01 \mathrm{RP}$ in the narrator-worded section, the occurrence of $06 \mathrm{MePs}$ and $01 \mathrm{BeP}$ is evidential for mentally probed-into characters. There are as many as $10 \mathrm{DMs}$ and $02 \mathrm{EMs}$ and the last 02 when-clause-sentences operate as generics to air the general plight of women.

Extract 32 contains 05 Matigari-sensed MePs. It must be remarked that the process 'sang', which is denotatively a ' $V P$ ', is contextually treated as an 'MeP' because it takes place in the character's mind. In addition, some of these MePs introduce sections of highly tonal streams of thought: the RR-section "\# ["whether he should ..... gathered there"]] is introduced by the MeP 'resisted' and all the string -"(\#) [[Ngagũro had told...... the armed might of the united dispossessed".]]- is part of the direct object of the MeP 'recalled'. The mental song between the marked strings is highly modulated: 01 GS, 03 'shall', 02 'refuse to', which can be replaced by 'won't'. There also are 02 other GSs, 24 DMs and 08 IMs in this extract. Likewise, (33) contains as many as $14 M e P s$, but just 03 TMPs, 03 MMPs and 03 RPs, namely in rankshifted or projected clauses. The dominant mood is $D M, 28$ in all, followed by $13 I M s, 04$ of which are elliptical, 03 EMs and 03 GSs. There also are 04 modulators 'cannot, would, would, come what may'. The 03 modalisers 'perhaps, might, might' may give the impression of an utterly external focalisation, but it should be noted they appear utterances in which Matigari interprets other characters' reactions as a second-level focaliser.

Extract 34 contains $02 \mathrm{MePs}$, with the generic/indefinite 'everybody' as 'senser', even though there are $02 \mathrm{RPs}$ and $01 \mathrm{MMP}$, mainly in subordinate positions:

(34) "[Everybody thought (MeP)](DM) [that it was ${ }^{(R P)}$ a VIP arriving ${ }^{(D M)}$. [Matigari must be ${ }^{(R P)}$ somebody indeed] ${ }^{(E M)}$. [How feared (MeP) he was, seeing] (EM) [that even such VIPs were coming (MMP) to wait for his Second Coming!] (EM)" (pp.163-64)

The passage contains 02 DMs but 03 EMs. It must be noted that, with the combination of a strong modaliser 'must' and the adjunct 'indeed', which, in a final position, operates as a strengthener to express emphasis, interest, incredulity or contempt, the third clause is taken as a modulated EM. In addition, the capitalisation of 'the Second Coming' likens Matigari to Christ, the Archangel, which is re-stressed in the capitalisation of 'He' in 'Who was He' (p. 158). In this novel, the political/ideological 'Second Coming' becomes a sort of resurrection of the Mau-Mau war against neo-colonialism through Matigari's resurgence and, especially, his rebirth through the young boy Muriuki, a Mau-Mau descendent. In fact, in this mental discourse-string, Muriuki appears as Matigari borne again, as he puts on the weapons buried by the latter to resume struggle against oppression:

(35) [Mũriüki watched(MeP) the rain] (DM) [as it fell(MMP)] (DM). [His glance swept(MeP) the bank] (DM) [along which he

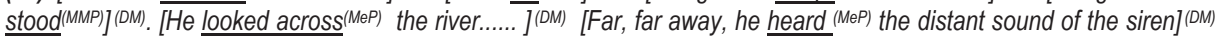
[as it called out(VP) to all the workers] (DM). [He recalled (MeP) the night of the workers' strike] (DM). [And suddenly, he seemed to hear (MeP) the workers' voices, the voices of the peasants, the voices of the students and of other patriots of all the different nationalities of the land, singing in harmony] ${ }^{(D M)}$ : ['Victory shall be ours!] ${ }^{(E M)}$ [Victory shall be ours! ](EM) [Victory shall be ours! ] ${ }^{(E M)}$ [Victory shall be ours!'] ${ }^{(E M)}$ (p.175)

The 06 main MePs, which have Mũriũki as senser, are evidence of internal focalisation. It must be noticed that the song represents the voice of the people (workers, peasants, students, and patriots) and is highly modulated with 04 "shall". This high modulation, reinforced by exclamative marks, emphasises the certainty of people's victory in the struggle against oppression. Similarly, the song and jubilation section (extract 36), which is taken as an internallyfocalised discourse string because it is part of the voices that the young boy 'seems to hear' in (36), is put in very strong moods: 23 EMs, 11 IMPs, 18 (EMs+ IMPs), 21 modulators (should: 01, must: 20), 11polarity adjuncts 'yes', and 03 interpersonal 'these' (Amoussou, 2014b). The combination of "modulation + exclamation" and of "imperative + exclamation" gives this section such an aggressively hostile tenor that cannot but threaten the ideological security of the rulers.

On the other hand, the narrator somehow projects some doubt, despair and pessimism in the mind of the authorities. Indeed, in extract 37, the comprador tycoons, represented by John Boy, are described as being greatly concerned. While the 03 passivised TMPs signal their passivity/inaction, the $06 \mathrm{MePs}, 02 \mathrm{BePs}$ and 05 mental IMs not only show that they are revealed from within but also that they undergo a deep psychological trauma/anxiety during the 
popular upheaval. It must be noted that the first IM is rewriteable (Barthes, 1974) and that the section "\#)[[who really was..... for a coup d'état]]' is introduced by the MeP 'wondered'. The near certainty of the comprador's interpretation of the insurrection as being a new insurgency or a coup plot is expressed through the strong modaliser 'must' and the polar EM with 'no!' Similarly, the security forces (38-40) and churchmen (41) are twice more 'worried' as their concerns are put into 13 and 11 mental IMs, respectively:

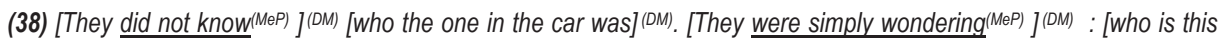
dignitary? [Everybody was whispering(MeP) the same question] (DM) . [Who was this dignitary in a black Mercedes-Benz?] ${ }_{(\mathrm{IM})}\left[\text { They all knew }{ }^{(\mathrm{MeP})}\right]^{(\mathrm{DM})}$ [how the government and the ruling party were worried about(MeP) Matigari's second coming] ${ }^{(D M)}$. [Even if Matigari were Christ himself] (DM), [he must be arrested immediately] ${ }^{(D M)}$ or [even (must) be shot on sight" ] (DM) (p.164)

(39) ["The security forces were asking themselves ${ }^{(M e P)}$ the same question]: [Where was Matigari ma Njirũũngi? ]" (p.169)

(40) [But the soldiers in the hunt were worried(MeP) $]^{(D M)}$. [Who is Matigari?] [they asked one another (MeP). [How on earth are we going to recognise him?] [What does he look like?] [What nationality is he?] [Is Matigari a man or a woman anyway? ] [ls he young or old?] [Is he fat or thin?] [Is he real or just a fragment of people's imagination? ] [Who or what really is Matigari ma Njirũũngi?] [ls he a person or a spirit?"] (p.170.)

(41) [They all shared the same hope $\left.{ }^{(M e P)}\right]^{(D M)}$ : [ that a miracle should take place] (DM). [But at the same time all

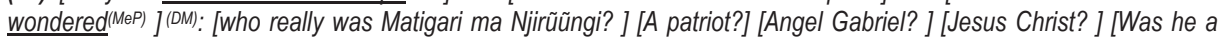
human being or a spirit? ] [ A true or false prophet? ] [A saviour or simply a lunatic?] [Was Matigari a man] or [was he a woman?] [A child or an adult?] [Or was he only an idea, an image, in people's minds?] [Who Was He?] (p.158)

The $08 \mathrm{MePs}$ in (38-40) indicate the individual and collective anxiety of the army over the arson, just as the 02 in (41) do for the believers. Here, the metaphor of modality 'they all knew how' translates the trueness of the rulers' fear while the 03 modulators 'must, must, should' express their necessity to stop the threat that Matigari represents. Overall, it can be forcefully argued the book's tenor is set mainly in the internally-focalised passages. The next section sums up and attempts and interpretation to the findings from the analysis.

\section{Recapitulation and Interpretation of the Findings}

Table 1 recapitulates mood and transitivity features of the internally-focalised discourse.

Table 1: Recapitulation of Transitivity and Mood Features of internal Focalisation in Matigari)

\begin{tabular}{|c|c|c|c|}
\hline \multicolumn{2}{|c|}{ Transitivity Features } & \multicolumn{2}{|c|}{ Mood Features } \\
\hline Process-Types & Quantity \& rate & Mood \& Modality Types & Quantity \& rate \\
\hline TMP & $20[08.20 \%]$ & DM & $278[51.67 \%]$ \\
\hline MMP & $30[12.29 \%]$ & IM & $140[26.41 \%]$ \\
\hline MeP & $143[58.60 \%]$ & EM & $86[15.99 \%]$ \\
\hline BeP & $33[13.52 \%]$ & IMP & $34[06.41 \%]$ \\
\hline RP & $17[06.97 \%]$ & GS/PS & 40 \\
\hline VP & $01[0.04 \%]$ & M+ & 134 \\
\hline RR & 80 & $M-$ & 17 \\
\hline Total processes counted: 244 & \multicolumn{2}{|c|}{ Total moods counted:538 } \\
\hline
\end{tabular}

It is must be noticed that these extracts are characterised by a dominance of mental-behavioural processes (about 72\%) and rewriteable narrated discourse, two key markers of internally focalised discourse (Uspensky, 1973; Rimmon-Kenan, 1983; Fowler, 1986; Amoussou, 2014). While this finding infirms the assumption among scholars and junior researchers that material processes always dominate in transitivity analyses, as cited in the introduction, it confirms that the mode of focalisation opted for by the writer influences transitivity choices (Amoussou, 2014: 129).

It must also be noted that even though DM appears to be dominant, it is important to realise that this is the mood used in almost all the 244 narrator-worded MeP-clauses and thus almost exclusively characterises the narrator's discourse. Of the remaining 294 moods that appear in the characters' discourse, the IM ranks highest (140/294: $47.61 \%)$. This being the mood par excellence to request information, its prevalence reflects the major characterfocaliser's nickname 'Macaria ma na Kihooto', meaning 'Seeker of Truth and Justice' (p.67). Next come the EM (86/294:29.25\%) and IMP (34/294:11.56\%), the moods to express wonder, admiration, emphasis, surprise, bewilderment, 
anger and indignation on the one hand, and demand, authority and obligation on the other (Eggins, 1994; Halliday \& Matthiessen, 2004; Bloor and Bloor, 2004). This means that there are about $11.56 \%$ of ordinary DMs in the characters' speech, the remaining clauses in this mood being in the form of proverbial/generic sentences. The profuse use of this kind of sentences "makes the reader bound to suspect the objectivity of someone who is so self-conscious, so confident and considered in his judgements (Fowler, 1986: 137), and is thus more a vehicle of modulation than of modalisation. Interestingly, there is an overwhelming outnumbering of modulators over the modalisers, which emphasises confidence, power, obligation, necessity, and truth-hood while that of modalisers mark subjectivity or caution or partiality (Fowler, 1986, Halliday, 1985a, Eggins, 1994).

The choice of a God-like/Christ-likened or mysterious character-focaliser may have greatly contributed to the authoritarian and confident tenor of discourse. Indeed, Matigari is portrayed as an indefinable and un-anthropomorphic character diversely referred to in ways in which God is in the Bible: "a Spirit" (John 4: 19-24); "a person, an individual, whose name is Jehovah" (Psalm 83; 18); "Father" (Matthew 6: 9); "the Rock," "the sun", 'the shield" (Deuteronomy 32: 4; Psalm 84:11). Similarly, Matigari is diversely referred to in these terms: "a middle-aged, tall and well-built man" (p.3); "a $d$ warf of a man ... when this dwarf stood up... he was transformed into a giant" ( $p .60)$; "a giant of a man" (p.64); "the man is a giant; he could easily touch the sky!" (p.76); "he is as tall as a giant"; "he is as little as a dwarf"; "a woman", "a man", "a child" (p.159); and is referred to with "he or she" (p.159), and as "a spirit" (p.170). Thus, he becomes mystical and difficult to define, just like God and spirit creatures. Moreover, he is likened to "a father" (p.57), to "thunder" (p.60) and to "a lion" (p.137), all symbols of power.

Above all, Matigari is a collective character as his name and pronominal reference show. The Gikuyu phrase "Matigari ma Njirũũngi" literally means "the patriots who survived the bullets" and it contextually refers to "freedom fighters who survived the liberation war or Mau Mau and their political offspring". Both the literal and contextual meanings hint to rebellion and revolutionary rebirth against the rulers. In introducing himself, Matigari uses the collective pronoun "we" ( $p$. 59, p. 76, p.124). On top of it all, he claims to be ageless: "I was there at the time of the Portuguese and at the time of the Arabs, and at the time of the British" (p.45). In an interview by Odisa and Anderson (2005), the writer sums up the collectiveness of this character as follows:

You see Matigari is a collective worker; he is not an individual in that sense. You remember how he kept changing and taking on different features. For example, when he thinks there is hope, his face becomes youthful. You remember how he outlined the history of Kenya to John Boy Jr.? He is indeed, all of us who aspire to positive change (p.4).

All these attributes (God, Father, Jesus, Thunder, Lion, agelessness, collectiveness) clearly give an impression of power which is translated into strong, confident, authoritarian and anti-government tenor of discourse.

\section{Conclusion}

At the end of this paper, it can be forcefully confirmed that linguistic analysis of fiction cannot be approached in the same way as that of informational discourse. The transitivity features uncovered emphasise the necessity to take into account narrative specifics such as modes of focalisation in the identification of process-types. In addition, the predominance of mental-behavioural processes means that second-thought is needed before pronouncements on the dominance of this and that type are made (Amoussou, 2014: 132-3). As the mode of discourse influences both transitivity and mood choices, it becomes necessary that careful selection is made along mode-lines so as to systematically compare texts from the same mode with a view to revealing its distinguishing features, or from different modes to see their similarities and dissimilarities. These considerations help to revisit a conclusion reached by Halliday (1973: 132) that the relevance and significance of a linguistics-oriented "inquiry into the language of a full-length prose work is notoriously difficult to assess". Eventually, the choice/concern of/in characters is found to have great an impact on the lexico-grammatical choices operated. All these linguistic features help to do justice to the Aristotelian relationship between language choice and depiction of character: "Character is that which reveals personal choice, the kind of things a man chooses or rejects when that is not obvious. Thus there is no revelation of character in speeches in which the speaker shows no preferences or aversions whatever" (Dorsh, 1965: 41).

\section{References}

Agbachi, Y. O. F. \& Egouleti, C. M. (2007). "Transitivity Patterns in Flora Nwapa's One is Enough," Unpublished Maitrise-Thesis, UAC. Ahouanvoedo, J. M.M. \& Gbékpodé, P. Z. (2009). Experiential Deviation or Contradiction: A Conclusion from the Transitivity Analysis of The Concubine. Unpublished Maitrise- Thesis, UAC.

Amoussou, C. Y. (2011). "Characterisation, Focalisation and Discourse in Ngũgĩ wa Thiong'o's Novels: A Functional Structuralist 
Approach." Ph. D-Dissertation, UAC.

Amoussou, C. Y. (2013). "Discourse Tenor, Context and Character in the Lawyer's Monster Parable (Petals of Blood); PARTICIP'ACTION, Volume6, N¹-janvier 2014: Lomé (Togo); pp. 147-170.

Amoussou, C. Y. (2015). "Functions of Filth Aesthetics and Estrangement in The Beautyful Ones Are Not Yet Born," Revue des Journées Portes Ouvertes; Flash, UAC.

Amoussou, C. Y. (Sept. 2015). "Mood, Interpersonal and Ideological Meaning Patterns in the 'Abiku' Poems (J.P. Clark; W. Soyinka); in International Journal of Language and Linguistics, Vol.2, No 3, Sept. 2015; pp.129 -138; ISSN 2374-8850(print), 2374 - 8869 (online); Center for Promoting Ideas: USA.

Amoussou, C. Y. (2016a). 'Exploring the Textual Metafunction in a Biblical-Fictional Parable in Ngũgĩ wa Thiong'o's Devil on the Cross,' in International Journal of Applied Linguistics \& English Literature-IJALEL, Australia: Australian International Academic Center PTY.LTD, Vol. 5, No5, pp. 215-27(Sept. 2016).

Amoussou, C. Y. (2016c). 'Semiotics of Power and Dictatorship in Ngũgĩ wa Thiong'o's Later Novels,' in Advances in Language and Literary Studies -ALLS. Australia: Australian International Academic Center, Vol. 7, No5, pp.208-221. (Oct. 2016)

Amoussou, C. Y. (2014). "Transitivity Analysis of Two Stretches of Narrated Mental Discourse from Ngũgî's Wizard of the Crow," Revue du CAMES, 2 nov.2014, Ouagadougou; pp.121-137. Barthes, R. (1974). S/Z. New York: Hill \& Wang. Brumfit, C. J. \&Carter R.A. (1991). Literature and Language Teaching. Oxford: Oxford University Press.

Chabi, K. (2004). "Transitivity Patterns in A Grain of Wheat," Unpublished Maitrise-Thesis, UAC.

Cohn, D. (1966). "Narrated Monologue: Definition of a Fictional Style," Comparative Literature, XVIII (1966), 97-112.

Crystal, D. (1968). What is linguistics? London: Arnold. Culler, J. (1975). Structuralist Poetics: Structuralism, Linguistics and the Study of Literature. London: Routledge \& Kegan Paul.

Cummings, M. \& Simmons, R. (1983): The Language of Literature: A Stylistic Introduction to the Study of Literature. Oxford: Pergamon Press. Ltd.

Dorsch, T. S. (ed.) (1965). Classical Literary Criticism. Harmondsworth: Penguin.

Eggins, S. (1994): An Introduction to Systemic-Functional Linguistics. London: Pinter Publishers Ltd.

Fontaine, L. (2013). Analysing English Grammar: A Systemic Functional Introduction. New York: Cambridge University Press.

Fowler, R. (1986). Linguistic Criticism. Oxford: Oxford University Press. Halliday, M. A. K. (1967). "The Linguistic Study of Literary Texts", in Chatman, S. \& Levin, S. R (eds). Essays on the Language of Literature. Boston: Houghton Mifflin; 217-23.

Halliday, M.A.K. (1970). "Descriptive Linguistics in Literary Studies", in Freeman, D. (1970). Linguistics and Literary Style. New-York: Holt, Rinehart and Winston, Inc. U.S.A. pp. 57-71

Halliday, M.A.K. (1971). "Linguistic Function and Literary Style: An Inquiry into the Language of William Golding's The Inheritors", in Chatman, S. B. (ed.) (1971). Literary Style. London \& New York: Oxford University Press.

Halliday, M. A. K. (1973). Explorations in the Functions of Language. London: Edward Arnold.

Halliday, M. A. K. (1985a). An Introduction to Functional Linguistics. London: Edward Arnold.

Halliday, M. A. K. \& Matthiessen, Ch. (2004). An Introduction to Functional Grammar (3rd ed.) London: Hodder Headline Group.

Halliday, M. A. K. \& Matthiessen, Ch. (2006). Construing Experience through Meaning: A Language-based Approach to Cognition. London, New York: Continuum.

Hasan, R. (1985/1989): Linguistics, Language and Verbal Art. Oxford: Oxford University Press.

Jakobson, R. (1960). "Concluding Remarks: Linguistics and Poetics," in Sebeok, T. (1960).Style in Language. Cambridge, Massachussetts: MIT Press.

Koussouhon, A. L. \& Amoussou, C. Y. (2015). "Characterisation, Authority and Ideology in Ngũgĩ's Devil on the Cross," The Mediterranean Journal of Social Sciences, Vol.6N4 S4, August 2015; MCSER Publishing, Rome, Italy; pp.138-148.

Littlewood, W. T. (1976). 'Literary and Informational Texts in Language Teaching.' Praxis1: 19-26.

Lyons, J. (ed,) (1970/ 1977). New Horizons in Linguistics. Harmondsworth, Middlesex: Penguin Books Ltd.

McCornell-Ginet, S. et al (eds) (1980). Women and Language in Literature and Society. Praeger: New York.

Ngũgĩ wa Th. (1981). Writers in Politics. London, Bedford, Ibadan, Nairobi: Heinemann Educational Ltd.

Odisa O. and Anderson, L. (2005) "A Kenyan Writer Speaks," in The Varsity, Art Section; Dec.24, 2005.

Uspensky, B. (1970, trs 1973). A Poetics of Composition: The Structure of the Artistic Text and Typology of Compositional Form. Berkeley: University of California Press.

Widdowson, H. G. (1975). Stylistics and the Teaching of Literature. London: Longman.

Yokossi, D. (2005). "Transitivity Patterns in Arrow of God," Unpublished Maitrise-Thesis, UAC. 